\title{
International Journal of African Studies
}

\section{Analysis of net trade, FDI and GDP growth using cointegration, VECM, Granger causality and a regression approach: A case study of Sub Saharan African region}

\author{
Vincent Tanoe ${ }^{1^{*}}$ \\ 'Independent, USA. E-mail: vtanoe@gmail.com
}

\section{Article Info}

Volume 1, Issue 2, June 2021

Received : 02 February 2021

Accepted : 15 May 2021

Published : 05 June 2021

doi: 10.51483/IJAFRS.1.2.2021.10-20

\begin{abstract}
Net trade and Foreign Direct Investment (FDI) are both important factors of economic growth and development in Sub Saharan African (SSA) region. Many different studies have shown the impact of trade and FDI in economy growth in SSA countries. However, few is known about the effect in SSA region in overall. To use these factors in policy making and development planning, the following questions need to be addressed. As both factors impact the economy growth, can net trade (NT) historical performance be used to forecast FDI? Is there any short-run or long-run relationship effect among GDP growth, FDI and net trade? This paper has implemented the cointegration methodology to analyze the impact of net trade and FDI on GDP growth, used the Vector Error Correction Model (VECM) for long-run and short-run relationship effect, an Ordinary Least Square (OLS) regression to determine the significant impact of FDI and net trade on GDP growth and finally the granger causality test. This study shows a positive long-run relationship effect of FDI on GDP. The positive short-run effect of both FDI and net trade is also detected on GDP growth. The regression result shows that net trade has a significant impact on GDP growth and finally from the Granger causality test, the study shows that net trade Grangercause FDI.
\end{abstract}

Keywords: GDP growth, FDI, Net trade, Cointegration, VECM, Granger causality

(C) 2021 Vincent Tanoe. This is an open access article under the CC BY license (https://creativecommons.org/licenses/by/4.0/), which permits unrestricted use, distribution, and reproduction in any medium, provided you give appropriate credit to the original author(s) and the source, provide a link to the Creative Commons license, and indicate if changes were made.

\section{Introduction}

Net trade has been one of the most important factors of GDP growth in the Sub Saharan African (SSA) region. In the past decades especially during the age of pre-colonial civilization, three of the major trade zones that SSA has been featured with are the trans-Saharan trade in the north, the Indian Ocean trade in the east and the Atlantic trade in the west. According to the World Bank, net trade in goods and services is derived by subtracting import of goods and services from the exports of goods and services. Back to the 1960s and 1980s, trade has shown a significant increased going from around $45 \%$ of GDP to almost $60 \%$ followed by a big drop earlier in the 1980 s. At the independence in 1960 for the majority of SSA countries, there was a positively promise of great expectations in economy growth. These expectations were broadly realized in the 1960s, when production grew and real per capita incomes increased appreciably (Calamitsis, 1999). But these expectations of potential growth declined in the 1980s which was caused by rising import prices and declining

\footnotetext{
* Corresponding author:Vincent Tanoe, Independent, USA. E-mail: vtanoe@gmail.com
} 
export prices in most of the poorer countries. The lack of appropriate economic policy led to that deterioration followed by the distortions prices, bad investments and increased of budget deficits. To respond to this crisis, new reforms such as adjustment and programs were moderately implemented in most of the SSA countries to address both existing macroeconomic problems and the structural constraint on economic growth. As a result, in the last three decades there was a significant increased started from $40 \%$ of GDP to almost $65 \%$ of GDP (Figure 1).

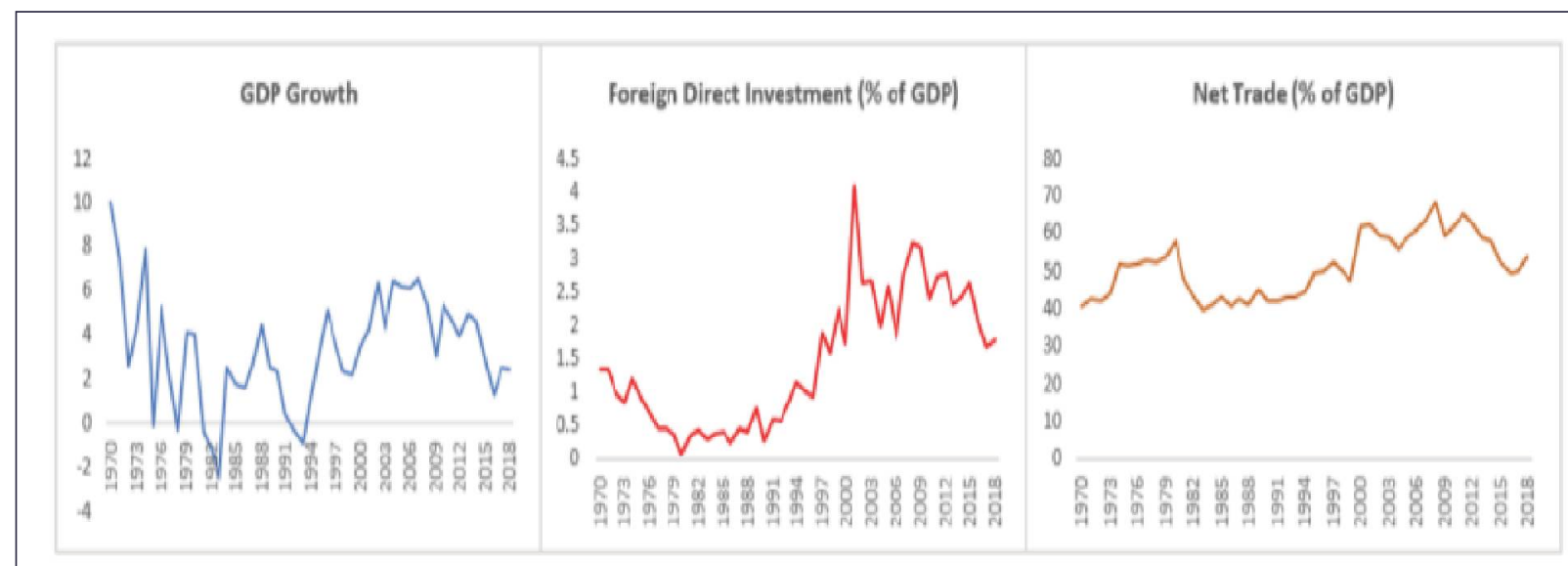

Figure 1: Showing the performance of Sub-Saharan Africa region growth, FDI and net trade

Trade sectors can be improved by the presence of capital which could also be generated by the Foreign Direct Investment (FDI). FDI brings more technologies, increases local productions and exports in an efficient manner, develops local skills and create jobs. FDI, in general, contributes to the sustainability of economic growth. in the case of Africa and especially in SSA region, FDI has become a very critical source of capital for investment in infrastructure and development to support local governments efforts in the key sectors of the economy (Anyanwu, 2006, 2011). Although SSA region does not benefit from the inflow of FDI as compared to other regions in the world, it remains a potential future inflow of FDI (Prince Jaiblai and Vijay Shenai, 2019). FDI represents a holistic important aspect of contributing to the development of exports and the improvement of the local productions. However, in order to attract more investment in an effective manner for development planning, one can ask the following question:

If a new development is designed to improve the net trade, what can be expected in the FDI as the result? Such questions require a statistical concept of causality that is based on prediction. Based on this rationale, I initiated this research for the statistical predictive modeling on my hypothesis describe below:

\section{Hypothesis: Does Net Trade Granger-Cause FDI?}

The aim of the current research is to determine, through analysis, if a signal of net trader "Granger-causes a signal FDI. The research also evaluates a cointegration method and Vector Error Correction Model (VECM) for an analysis of long-run and short run relationship and finally the impact of net trade and FDI on GDP growth in SSA using a linear regression model. This paper uses the World Bank indicators data such as net trade, FDI and GDP growth (all variables are in percentage of GDP).

The remainder of the paper is organized as follows: Section II provides an overview of a theoretical and empirical research of net trade, FDI in the SSA regions also the performance as compared the other regions. In Section III, the econometric and statistical models used, data sources, and definitions are also covered. Section IV presents how the experimental results of the econometric and statistical models are estimated from the data and the results are interpreted. Section V concludes the paper and provides policy recommendations.

\section{Literature review}

Several recent studies have shown the effect of net trade, FDI and other determinants factors on economic growth in SSA countries. Also, recent researches have been conducted in which scholars try to show the simultaneous effect of trade and investment on growth in SSA using a cross sectional analysis. Fredrick et al. (2019) examined the role of trade and investment on SSA region's GDP growth. Their study showed that trade domestic investment and import affect growth in the region positively while export affect growth negatively. The empirical study of Onafowora and Owoye (2008) showed that export has positive impact on growth using the cross-sectional analysis applied on 12 samples of 12 
SSA countries. An extensive review on the relationship between trade openness and growth since the 1970s is also found in (Harrison and Rodriguez-Clare, 2009) and covers almost 180 studies.

Recent studies have addressed a strategy for post-crisis growth using export and export diversification in the SSA (Vera Songue and Deborah Winkler, 2012). The authors found that the effect of exports on growth and employment is also influenced by export destination. Furthermore, the diversification of export can be also positively related to economic growth. In the other aspect of the previous analysis based on cross-country empirical research in 1980s Lewer and Berg (2003) found that the association between trade and economic growth was statistically significant. Their findings aligned to many empirical investigations regarding the size of the relationship which showed in average that a one percent increase in export was associated with one-fifth percent point increase in the Gross National Product (GNP).

In addition to the positive impact of trade on growth, FDI can bring important capital to countries. Prince Jaiblai and Vijay Shenai (2019) showed in their study that, over a period of time, high inflows of FDI in relation to GDP appear to be attracted to the markets with better infrastructures. Acquah and Jessie Woraewa (2017) operationalized their examination of the impact of FDI on domestic investment for 36 countries in SSA. Their results showed that financial development and human capital tend to lessen the crowding-in effect of FDI on domestic investment in SSA and could also be eventually led to a crowding-out of domestic investment after a certain threshold. Another evidence of an existing research using a panel data from 38 SSA countries and a dynamic system Generalized Method Moments (GMM), showed that inward FDI is more dynamic in non-resource-rich than in resource-rich countries and the impact of natural resource endowment and macroeconomic factors are more robust in the stock than it is the flow of inward FDI (Ezeoha Abel and Cattaneo Nicola, 2012).

Other research studies have recently been implemented on trade openness instead of the empirical perspective of trade as exports. Trade openness is widely defined as a nature of exports and imports activities of a country. Historical literature has shown that trade in terms of exports and imports positively impacted growth and also brought an important progress for the economic (Rodrik, 1999). Despite the scholar's contribution of the impact, few studies have discussed on the degree of causality between the net trade and FDI. This research is focused on the association of net trade, FDI and growth.

\section{Methodology}

\subsection{Ordinary Least Square (OLS), cointegration and Vector Error Correction Model (VECM)}

The present study uses world bank data indicators (World Bank) from 1970 to 2018. This paper aims to first apply a neoclassical augmented growth model that was developed by Mankiw et al. (1992) which estimated the impact of trade (Net Trade) and investment (FDI) on growth. Following the empirical approach, the study uses the Net Trade (\% of GDP), FDI (\% of GDP), the growth (GDP) in Sub-Saharan Region. The variables of interests in this study are the Net Trade and the FDI. The simplest model to capture the impact of the variables on GDP is specified as:

$$
G D P_{t}+\alpha+\beta_{1} N T_{t}+\beta_{2} F D I_{t}+\varepsilon_{t}
$$

where $G D P_{t}$, the growth at time $t$, is a measurement of the economic growth in the SSA region. $\alpha$ shows the SSA-specific effect. $N T_{t}$ is the Net trade being the trade measures that implies total exports minus total imports of the SSA region at time $t . F D I_{t}$ is the foreign direct investment for the SSA region at time $t$. The $\varepsilon_{t}$, is defined as the error term, $\beta_{1}, \beta_{2}$ are the respective parameter coefficients of NT and FDI to be estimated in the study.

\subsection{Estimations of the models}

In this study, I estimate the long-run and short-run relationship among the growth, the Foreign Direct Investment (FDI), the Net Trade (NT) after testing the stationarity of the data. To explore the impact of FDI and Net Trade on GDP growth, I applied the cointegration Johansen test method and finally used the VECM to estimate the long-run and shortrun effects. The equation of VECM is described as:

$$
\Delta \overline{G D P}_{t}=a+\sum_{i=0}^{L} \hat{\beta}_{i} * \Delta G D P_{t-i}+\sum_{i=0}^{L} \hat{\delta}_{i} * \Delta N T_{t-i}+\sum_{i=0}^{L} \hat{\gamma}_{i} * \Delta F D I_{t-i}+\hat{\rho}^{*} \hat{\varepsilon}_{t-i}
$$

where $L$ represents the number of lags in the model, rho hat $(\hat{\rho})$ the estimated long-run relationship coefficient, and eta hat $(\hat{\varepsilon})$ the deviation of from the long-run relationship in Equation (1). 


\subsection{Granger causality}

The second approach that I explore in this study is the evaluation of the granger causality between the FDI and the Net Trade (NT). Granger causality is one of the popular econometric method that is used to study the causal relationship between two or more random variables (Granger, 1969). Following the definition in the context of this paper, if we consider the two predictive variables NT and FDI and assume that NT Granger-causes FDI, then the past information of NT can be used to forecast FDI. Granger causality is a probalistic method which takes in account the causality and it is also applied in the model of linear regression.

$$
\begin{aligned}
& N T_{t}=\sum_{i=0}^{r} b_{11, i} * N T_{t-i}+\sum_{i=0}^{r} b_{21, i} * F I_{t-i}+\mu_{1, t} \\
& F D I_{t}=\sum_{i=0}^{r} b_{21, i} * N T_{t-i}+\sum_{i=0}^{r} b_{22, i} * F D I_{t-i}+\mu_{2, t}
\end{aligned}
$$

where $r$ is the maximum lagged observations in the model. $b$ is the matrix that expresses the parameters of the model and $\mu_{1}$ and $\mu_{2}$ are the variances that decreased by the inclusion of the predictive variables.

\section{Results and discussion}

I first conducted a stationary test at level to see if the data is stationary (Table1). I found that at level the data is not stationary which is not the case after I used the first difference (Table2). To evaluate the long-run relationship before

\begin{tabular}{|l|c|c|c|c|}
\hline \multicolumn{1}{|l|}{ Table 1: Unit root test at level for stationarity } & Statistic & Prob.** & Cross-sections & Obs. \\
\hline Method & & & & \\
\hline Null: Unit root (assumes common unit root process) & -1.19213 & 0.1166 & 3 & 143 \\
\hline Levin, Lin \& Chu t* & -1.33877 & 0.0903 & 3 & 140 \\
\hline Breitung t-stat & & & 3 & 143 \\
\hline Null: Unit root (assumes individual unit root process) & -1.63706 & 0.0508 & 3 & 143 \\
\hline Im, Pesaran and Shin W-stat & 14.5296 & 0.0242 & 3 & 144 \\
\hline ADF - Fisher chi-square & 17.4078 & 0.0079 & 3 & 3 \\
\hline PP - Fisher chi-square & & & 3 \\
\hline Note: $* *$ Probabilities for Fisher tests are computed using an asymptotic chi-square distribution. All other tests assume \\
\hline$\quad$ asymptotic normality.
\end{tabular}

\section{Table 2: Unit root test at $1^{\text {st }}$ difference for stationarity}

\begin{tabular}{|l|c|c|c|c|}
\hline Method & Statistic & Prob.** & Cross-sections & Obs. \\
\hline Null: Unit root (assumes common unit root process) & & & & \\
\hline Levin, Lin \& Chu t* & -14.9432 & 0.0000 & 3 & 141 \\
\hline Breitung t-stat & -10.0147 & 0.0000 & 3 & 138 \\
\hline Null: Unit root (assumes individual unit root process) & & & 3 & 141 \\
\hline Im, Pesaran and Shin W-stat & -15.3065 & 0.0000 & 3 & 141 \\
\hline ADF - Fisher chi-square & 144.062 & 0.0000 & 3 & 141 \\
\hline PP - Fisher chi-square & 159.675 & 0.0000 & 3 & \\
\hline Note: $* *$ Probabilities for Fisher tests are computed using an asymptotic chi-square distribution. All other tests assume \\
\hline \multicolumn{2}{|l}{ asymptotic normality. }
\end{tabular}


applying the VECM. In Table 3, the result shows that there is no unit root at $1^{\text {st }}$ difference of the data which shows a stationarity. The results of trace test and the maximum Eigenvalue from Table 4 shows an existence of three cointegration equations.

\begin{tabular}{|c|c|c|c|c|c|c|}
\hline Lag & $\log \mathrm{L}$ & LR & FPE & AIC & $\mathrm{SC}$ & HQ \\
\hline 0 & -289.2011 & NA & 87.62867 & 12.98672 & 13.10716 & 13.03162 \\
\hline 1 & -239.9907 & 89.67237 & 14.69293 & 11.19959 & $11.68136^{*}$ & $11.37919^{*}$ \\
\hline 2 & -229.4611 & $17.78338 *$ & $13.81301 *$ & $11.13160^{*}$ & 11.97471 & 11.44591 \\
\hline 3 & -220.9873 & 13.18138 & 14.35334 & 11.15499 & 12.35943 & 11.60400 \\
\hline 4 & -213.4503 & 10.71938 & 15.75516 & 11.22001 & 12.78579 & 11.80372 \\
\hline
\end{tabular}

\begin{tabular}{|c|c|c|c|c|}
\hline \multicolumn{5}{|c|}{ Unrestricted cointegration rank test (trace) } \\
\hline Hypothesized no. of CE(s) & Eigenvalue & Trace statistic & 0.05 Critical value & Prob.** \\
\hline None* & 0.601464 & 91.34382 & 29.79707 & 0.0000 \\
\hline At most $1 *$ & 0.443319 & 49.02573 & 15.49471 & 0.0000 \\
\hline At most $2 *$ & 0.381225 & 22.08063 & 3.841465 & 0.0000 \\
\hline
\end{tabular}

Note: Trace test indicates 3 cointegrating eqn(s) at the 0.05 level; * denotes rejection of the hypothesis at the 0.05 level; and ** MacKinnon-Haug-Michelis (1999) $p$-values.

Unrestricted cointegration rank test (Maximum Eigenvalue)

\begin{tabular}{|l|c|c|c|}
\hline Hypothesized no. of CE(s) & Eigenvalue & Max-Eigen Statistic & 0.05 Critical value \\
\hline None* & 0.601464 & 42.31809 & 21.13162 \\
\hline At most 1* & 0.443319 & 26.94511 & 14.26460 \\
\hline At most 2* & 0.381225 & 22.08063 & 3.841465 \\
\hline
\end{tabular}

Note: Max-eigenvalue indicates 4 cointegrating eqn(s) at the 0.05 level; $*$ denotes rejection of the hypothesis at the 0.05 level; and ** MacKinnon-Haug-Michelis (1999) $p$-values.

After the stationarity and the cointegration are met, I lag the residuals by one period estimate the VECM (equation 2). The goal of using the VECM estimation model is to calibrate the short-run and the long-run changes in the variables and deviations from an equilibrium relationship that determines the behavior run. Both short-run and long-run relationship effects and cointegration equations results of growth of GDP, FDI and net trade are shown in Table 5. From the cointegration equation, we can see that the coefficient of the FDI (-1.731467) positively impacts the Growth in the long run. But this is not the case for Net Trade's coefficient (0.058653) which negatively impact the growth in the long run (Equation 5).

$$
\mathrm{GDP}_{\mathrm{t}-1}=1.731467 \mathrm{FDI}_{\mathrm{t}-1}-0.0586353 \mathrm{~N} \mathrm{~T}_{\mathrm{t}-1}+3.647204
$$

The result shows that cointegration equation coefficient is -0.959968 in Table 5 is significant with a probability of 0.000 (Table 6). With a negative coefficient $(-0.959968)$ and a probability value of 0.000 , the long run relationship is established. The predictors variables influence the dependent variable by $53 \%\left(R^{2}\right)$. In addition, I can also see that the FDI has a long run positive impact on growth. 


\begin{tabular}{|c|c|c|c|}
\hline \multicolumn{2}{|l|}{ Cointegrating Eq: } & \multicolumn{2}{|c|}{ CointEq1 } \\
\hline \multicolumn{2}{|l|}{$\operatorname{GDP}(-1)$} & \multicolumn{2}{|c|}{1.000000} \\
\hline \multicolumn{2}{|l|}{$\operatorname{FDI}(-1)$} & \multicolumn{2}{|c|}{$\begin{array}{c}-1.731467 \\
(0.50868) \\
{[-3.40388]}\end{array}$} \\
\hline \multicolumn{2}{|l|}{$\mathrm{NT}(-1)$} & \multicolumn{2}{|c|}{$\begin{array}{l}0.058653 \\
(0.06626) \\
{[0.88517]}\end{array}$} \\
\hline \multicolumn{2}{|l|}{$\mathrm{C}$} & \multicolumn{2}{|c|}{-3.647204} \\
\hline Error correction: & D(GDP $)$ & $\mathbf{D}(\mathbf{F D I})$ & $\mathrm{D}(\mathrm{NT})$ \\
\hline CointEq1 & $\begin{array}{c}-0.959968 \\
(0.20209) \\
{[-4.75026]}\end{array}$ & $\begin{array}{c}-0.015171 \\
(0.05247) \\
{[-0.28911]}\end{array}$ & $\begin{array}{c}-0.542051 \\
(0.43218) \\
{[-1.25422]}\end{array}$ \\
\hline $\mathrm{D}(\mathrm{GDP}(-1))$ & $\begin{array}{l}0.021912 \\
(0.16441) \\
{[0.13327]}\end{array}$ & $\begin{array}{c}-0.003325 \\
(0.04269) \\
{[-0.07788]}\end{array}$ & $\begin{array}{l}0.546186 \\
(0.35162) \\
{[1.55335]}\end{array}$ \\
\hline $\mathrm{D}(\mathrm{GDP}(-2))$ & $\begin{array}{c}-0.184261 \\
(0.13193) \\
{[-1.39666]}\end{array}$ & $\begin{array}{c}-0.028079 \\
(0.03426) \\
{[-0.81966]}\end{array}$ & $\begin{array}{c}-0.414669 \\
(0.28215) \\
{[-1.46970]}\end{array}$ \\
\hline $\mathrm{D}(\mathrm{FDI}(-1))$ & $\begin{array}{c}-2.093529 \\
(0.74486) \\
{[-2.81064]}\end{array}$ & $\begin{array}{r}-0.588108 \\
(0.19341) \\
{[-3.04075]}\end{array}$ & $\begin{array}{c}-2.235633 \\
(1.59295) \\
{[-1.40345]}\end{array}$ \\
\hline $\mathrm{D}(\mathrm{FDI}(-2))$ & $\begin{array}{c}-1.514038 \\
(0.62690) \\
{[-2.41513]}\end{array}$ & $\begin{array}{c}-0.004462 \\
(0.16278) \\
{[-0.02741]}\end{array}$ & $\begin{array}{c}-2.343088 \\
(1.34068) \\
{[-1.74769]}\end{array}$ \\
\hline $\mathrm{D}(\mathrm{NT}(-1))$ & $\begin{array}{c}0.155608 \\
(0.08370) \\
{[1.85920]}\end{array}$ & $\begin{array}{l}0.069699 \\
(0.02173) \\
{[3.20716]}\end{array}$ & $\begin{array}{l}0.087491 \\
(0.17899) \\
{[0.48880]}\end{array}$ \\
\hline $\mathrm{D}(\mathrm{NT}(-2))$ & $\begin{array}{l}0.247181 \\
(0.09003) \\
{[2.74552]}\end{array}$ & $\begin{array}{l}0.015061 \\
(0.02338) \\
{[0.64426]}\end{array}$ & $\begin{array}{l}0.193818 \\
(0.19254) \\
{[1.00664]}\end{array}$ \\
\hline $\mathrm{C}$ & $\begin{array}{c}-0.072537 \\
(0.26809) \\
{[-0.27057]}\end{array}$ & $\begin{array}{l}0.001586 \\
(0.06961) \\
{[0.02279]}\end{array}$ & $\begin{array}{c}0.239242 \\
(0.57333) \\
{[0.41729]}\end{array}$ \\
\hline$R^{2}$ & 0.530576 & 0.443403 & 0.220853 \\
\hline Adj. $R^{2}$ & 0.444103 & 0.340872 & 0.077326 \\
\hline Sum sq. resids & 121.8502 & 8.215450 & 557.2933 \\
\hline SE equation & 1.790694 & 0.464969 & 3.829571 \\
\hline F-statistic & 6.135757 & 4.324568 & 1.538755 \\
\hline Log likelihood & -87.67665 & -25.65080 & -122.6435 \\
\hline
\end{tabular}


Table 5 (Cont.)

\begin{tabular}{|l|c|c|c|}
\hline Error correction: & D(GDP) & D(FDI) & D(NT) \\
\hline Akaike AIC & 4.159854 & 1.463078 & 5.680153 \\
\hline Schwarz SC & 4.477879 & 1.781103 & 0.998178 \\
\hline Mean dependent & -0.005217 & 0.017174 & 3.986814 \\
\hline S.D. dependent & 2.401731 & 0.572715 & 8.380969 \\
\hline Determinant resid covariance (dof adj.) & & 4.724671 \\
\hline Determinant resid covariance & & -231.5279 \\
\hline Log likelihood & & 11.24034 \\
\hline Akaike information criterion & & 12.31368 \\
\hline Schwarz criterion & & 27 \\
\hline Number of coefficients & & \\
\hline
\end{tabular}

Table 6: Coefficient of probability values

\begin{tabular}{|c|c|c|c|c|}
\hline & Coefficient & Std. Error & $t$-Statistic & Prob. \\
\hline $\mathrm{C}(1)$ & -0.959968 & 0.202087 & -4.750264 & 0.0000 \\
\hline $\mathrm{C}(2)$ & 0.021912 & 0.164415 & 0.133273 & 0.8942 \\
\hline $\mathrm{C}(3)$ & -0.184261 & 0.131930 & -1.396656 & 0.1652 \\
\hline $\mathrm{C}(4)$ & -2.093529 & 0.744859 & -2.810640 & 0.0058 \\
\hline $\mathrm{C}(5)$ & -1.514038 & 0.626897 & -2.415131 & 0.0173 \\
\hline $\mathrm{C}(6)$ & 0.155608 & 0.083696 & 1.859200 & 0.0656 \\
\hline$C(7)$ & 0.247181 & 0.090031 & 2.745515 & 0.0070 \\
\hline $\mathrm{C}(8)$ & -0.072537 & 0.268087 & -0.270573 & 0.7872 \\
\hline $\mathrm{C}(9)$ & -0.015171 & 0.052474 & -0.289110 & 0.7730 \\
\hline$C(10)$ & -0.003325 & 0.042692 & -0.077883 & 0.9381 \\
\hline $\mathrm{C}(11)$ & -0.028079 & 0.034257 & -0.819659 & 0.4141 \\
\hline$C(12)$ & -0.588108 & 0.193409 & -3.040748 & 0.0029 \\
\hline $\mathrm{C}(13)$ & -0.004462 & 0.162779 & -0.027409 & 0.9782 \\
\hline$C(14)$ & 0.069699 & 0.021732 & 3.207160 & 0.0017 \\
\hline$C(15)$ & 0.015061 & 0.023377 & 0.644264 & 0.5207 \\
\hline$C(16)$ & 0.001586 & 0.069611 & 0.022788 & 0.9819 \\
\hline$C(17)$ & -0.542051 & 0.432183 & -1.254217 & 0.2123 \\
\hline $\mathrm{C}(18)$ & 0.546186 & 0.351617 & 1.553354 & 0.1231 \\
\hline $\mathrm{C}(19)$ & -0.414669 & 0.282146 & -1.469696 & 0.1444 \\
\hline
\end{tabular}




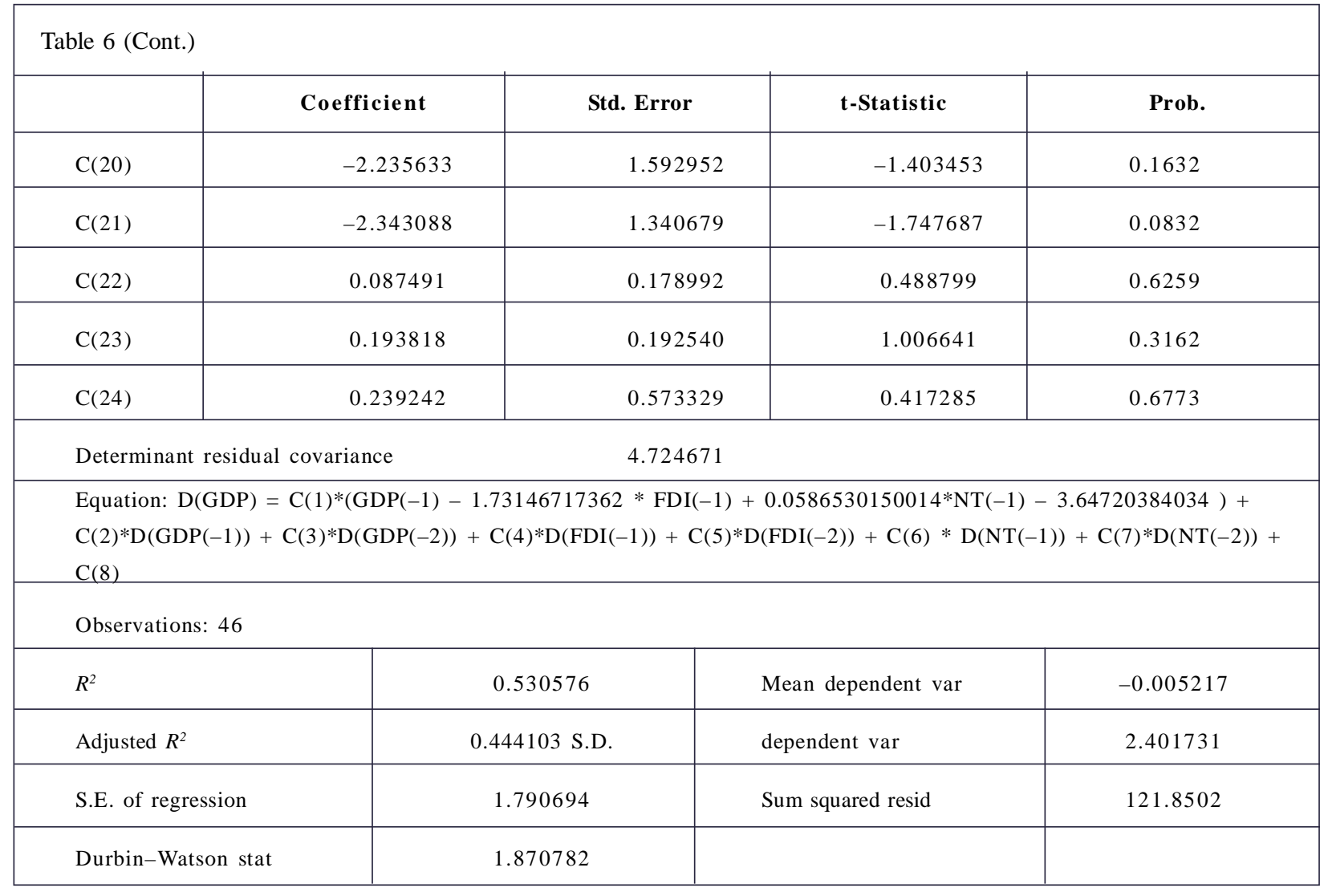

This study used the Breusch-Godfrey LM Test to detect the serial correlation. The results provided in Table 7 show no serial correlation in the model of variables GDP, FDI and net trade. The stability of the model using the Cusum method is also analyzed and Figure 2 shows that the model is stable using variable growth as a dependent variable and both FDI and net trade as independent variables.

\section{Table 7: Breush-Godfrey serial correlation LM test}

Breusch-Godfrey serial correlation LM test:

Null hypothesis: No serial correlation at up to 2 lags

\begin{tabular}{|l|c|c|c|}
\hline$F$-statistic & 0.984523 & Prob. F(2,36) & 0.3835 \\
\hline Obs* $R^{2}$ & 2.385526 & Prob. Chi-Square (2) & 0.3034 \\
\hline
\end{tabular}

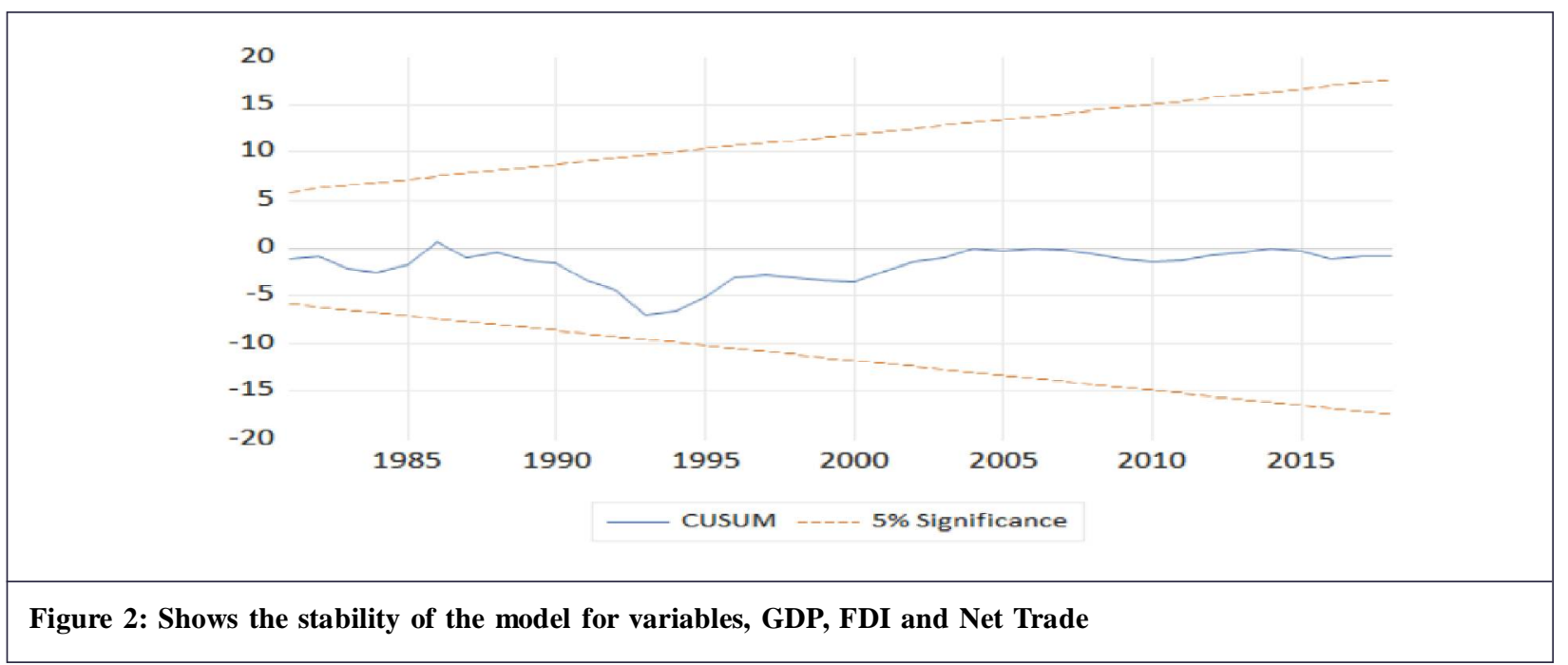


The OLS regression using the stationary variables at $1^{\text {st }}$ differenced is also conducted. From the results shown in Table 8, while the FDI is not significant, one unit changed of net trade positively affects the growth by 0.20 in point average with a significant $p$-value of 0.0245 .

\begin{tabular}{|c|c|c|c|c|}
\hline \multicolumn{5}{|c|}{$\begin{array}{l}\text { Dependent Variable: D_GDP } \\
\text { Method: Least Squares } \\
\text { Sample (adjusted): } 19712018 \\
\text { Included observations: } 48 \text { after adjustments }\end{array}$} \\
\hline Variable & Coefficient & Std. Error & $t$-Statistic & Prob. \\
\hline D_FDI & -0.464410 & 0.621569 & -0.747157 & 0.4589 \\
\hline D_NT & 0.208302 & 0.089479 & 2.327947 & 0.0245 \\
\hline $\mathrm{C}$ & -0.211063 & 0.345011 & -0.611757 & 0.5438 \\
\hline$R^{2}$ & 0.111877 & \multicolumn{2}{|c|}{ Mean dependent var } & -0.157917 \\
\hline Adjusted $R^{2}$ & 0.072405 & \multicolumn{2}{|c|}{ S.D. dependent var } & 2.475442 \\
\hline S.E. of regression & 2.384141 & \multicolumn{2}{|c|}{ Akaike info criterion } & 4.636016 \\
\hline Sum squared resid & 255.7857 & \multicolumn{2}{|c|}{ Schwarz criterion } & 4.752966 \\
\hline Log likelihood & -108.2644 & \multicolumn{2}{|c|}{ Hannan-Quinn criterion. } & 4.680212 \\
\hline$F$-statistic & 2.834342 & \multicolumn{2}{|c|}{ Durbin-Watson stat } & 2.714198 \\
\hline $\operatorname{Prob}(F$-statistic $)$ & 0.069285 & & & \\
\hline
\end{tabular}

Table 9: VEC Granger causality/Block exogeneity Wald test

Dependent variable: D(SSA_GDP)

\begin{tabular}{|c|c|c|c|}
\hline Excluded & Chi-sq. & df & Prob. \\
\hline $\mathrm{D}(\mathrm{FDI})$ & 8.467420 & 2 & 0.0145 \\
\hline $\mathrm{D}(\mathrm{NT})$ & 9.242219 & 2 & 0.0098 \\
\hline All & 11.33881 & 4 & 0.0230 \\
\hline \multicolumn{4}{|c|}{ Dependent variable: $\mathrm{D}(\mathrm{FDI})$} \\
\hline Excluded & Chi-sq. & df & Prob. \\
\hline $\mathrm{D}(\mathrm{GDP})$ & 0.788261 & 2 & 0.6743 \\
\hline $\mathrm{D}(\mathrm{NT})$ & 10.28734 & 2 & 0.0058 \\
\hline All & 10.40668 & 4 & 0.0341 \\
\hline \multicolumn{4}{|c|}{ Dependent variable: $\mathrm{D}(\mathrm{NT})$} \\
\hline Excluded & Chi-sq. & df & Prob. \\
\hline $\mathrm{D}(\mathrm{GDP})$ & 8.524423 & 2 & 0.0141 \\
\hline $\mathrm{D}(\mathrm{FDI})$ & 3.168715 & 2 & 0.2051 \\
\hline All & 9.872496 & 4 & 0.0426 \\
\hline
\end{tabular}


The last part of this study is destinated to both Granger causality Wald test and the Granger causality pairwise test. In the Wald test (Table 9), with have three different scenarios. In the first scenario where GDP growth is dependent and both FDI and net trade are independent, it shows that FDI and net trade have both short-run influence on GDP with respective chi-square values of 8.46 and 9.24 and respective $p$-values of 0.0145 and 0.0098 . The second scenario, with FDI as dependent variable, only shows that net trade has a short-run influence on FDI while GDP does not. In the third scenario with net trade as dependent variable, GDP growth has a short-run impact on trade while the FDI does not. Finally, all three results in overall show a short-run impact when independent variables are put together in each scenario.

In the Granger causality pairwise test (Table 10), the hypothesis question is answered. The result shows that net trade does Granger-cause FDI which means that the past of net trade can be used to forecast FDI.

\begin{tabular}{|c|c|c|c|}
\hline \multicolumn{4}{|l|}{ Table 10: Pairwise Granger causality test } \\
\hline \multicolumn{4}{|l|}{$\begin{array}{l}\text { Pairwise Granger causality tests } \\
\text { Date: 10/03/20 Time: 00:16 } \\
\text { Sample: } 19702018 \\
\text { Lags: } 2\end{array}$} \\
\hline Null hypothesis: & Obs. & F-Statistic & Prob. \\
\hline D_FDI does not Granger-cause D_GDP & 46 & 0.15065 & 0.8606 \\
\hline D_GDP does not Granger-cause D_FDI & & 0.64030 & 0.5323 \\
\hline D_TRADE does not Granger-cause D_GDP & 46 & 0.19467 & 0.8239 \\
\hline D_GDP does not Granger-cause D_TRADE & & 3.18373 & 0.0518 \\
\hline D_TRADE does not Granger-cause D_FDI & 46 & 6.14081 & 0.0046 \\
\hline D_FDI does not Granger-cause D_TRADE & & 0.58383 & 0.5623 \\
\hline
\end{tabular}

\section{Conclusion}

GDP growth in SSA region is designed to represent a holistic measure of the economic performance of the region. From 1970 to 2018, SSA region has shown an average growth of 3.34\%. Many factors such as economic policy, governance, exchanges rate, foreign policies, trade policy and economic stability impact GDP growth. However, in order to use the GDP growth indicators data in efficient manner for policy making and development planning, a predictive model need to be analyzed. In this paper, I evaluate the connectivity among net trade, FDI and GDP growth. To measure the impact effect of FDI and Net Trade on GDP growth, Johnsen's cointegration method followed by VECM has been applied for short-run and long-run relationship effects. from this, a positive significant longrun relationship effect of FDI is identified on GDP growth and this was not the case for net trade which showed a negative impact on GDP in the long run relationship.

In addition, two Granger causality tests have been used in this study. In the Wald test, the empirical result from the first scenario with GDP growth as a dependent variable shows that both FDI and net trade have significant short-run effect on GDP growth. The second scenario with FDI as dependent variable, only Net Trade shows a short-run significant effect. Finally, in the last scenario with net trade as dependent variable, only GDP growth shows a significant short-run effect of trade while FDI does not.

The Granger causality pairwise test is used in this study to answer the hypothesis question. The test result from the Pairwise test, shows that net trade does Granger-cause FDI. Hence, the study used an OLS regression approach to analyze the impact of FDI and trade on GDP growth. The result from the regression shows that one unit changed in net trade significantly impact GDP by 0.20 point in average.

In the recent years SSA region has benefitted from FDI in several sectors such as infrastructure, local government businesses and retails stores. To increase and maintain the FDI inflows, governments is SSA region need to have good policy and economy stability. Another import factor is net trade. The GDP growth in SSA region is also impacted by Net Trade. This sector needs strong policy making and development planning. To boost the productivity in trade, governments need to consider the allocation of investment flow in industrialization which will allow the transformation of raw materials. 


\section{References}

Acquah, Jessie, Woraewa. (2017). Impact of Foreign direct investment of domestic investment: evidence from SubSaharan Africa. University of Lethbridge, Faculty of Arts and Science.

Anyanwu, John. (2006). Promoting of investment in Africa. African Development Review. 18, 42-71.

Anyanwu, John. (2011). Determinants of foreign direct investment inflows to Africa, 1980-2007. African Development Bank Group Working Paper. September, pp. 1-31. Available online: https://journals.sagepub.com/content/20/12/ 89. short\% 5 Cnhttp://www.afdb.org/fileadmin/uploads/afdb/Documents/\%20Publications/ WORKING136DeterminantsofForeignDirectInvestmentInflowsToAfrica1980-2007AS.pdf (accessed on August 1,2019).

Calamitsis, Evangelos, A. (1999). Adjustment and growth in Sub-Saharan Africa: https://www.imf.org/external/pubs/ft/ fandd/1999/03/calamits.htm

Ezeoha, Abel. and Cattaneo, Nicolette. (2012). FDI flows to Sub-Saharan Africa: The impact of finance, institutions and natural resources endowment. Journal of Comparative Economic Studies. DO-10.1057/ces.2012.18

Fredrick, Ikpesu., Olusegnu, Vincent. and Olamitunji, Dakare. (2019). Growth effect of trade and investment in SubSaharan Africa countries: Empirical insight from panel corrected standard error (PCSE) technique, Cogen Economic and Finance. 7(1), 1607127, DOI:10.1080/23322039.2919.1607127

Granger. (1969). Econometrica Models and Cross-spectral Methods. 37(3), 424 -438.

Harrison, A. and Rodriguez-Clare, A. (2009), Trade, Foreign Investment and Industrial Policy for Developing Countries. NBER Working Paper No.15261.

Lewer, J.J. and Berg, H.V.D. (2003). How large is international trade's effect on economic growth?. Journal of Economic Surveys. 17(3), 363-396. doi:10.1111/1467-6419.00198

Mankiw, N.G., Romer, D. and Weil, D.N. (1992). A contribution to the empirics of economic growth. The Quarterly Journal of Economics. 107(2), 407-437. doi:10.2307/2118477

Onafowora, Olugbenga, A. and Owoye, Oluwole. (2008). Exchange rate volatility and export growth in Nigeria. Applied Economics. 40(12), 1547-1556, DOI: 10.1080/00036840600827676

Prince, Jaiblai. and Vijay, Shenai. (2019). The determinants of FDI in Sub-Saharan Economics: A study of data from 1990 -2017. International Journal of Financial Studies, August.

Rodrik, D. (1999). The new global economy and developing countries: Making openness work (Vol.24). Washington, DC: Overseas Development Council.

Vera, Songue. and Deborah, Winkler. (2012). Exports and export diversification in Sub-Saharan Africa: A strategy for post-crisis growth. Africa Growth Initiave at Brookings, Working Paper 3, December 2012.

Cite this article as: VincentTanoe(2021). A nal ysis of net trade, FDI and GDP growth using cointegration, VECM, Granger causality and a regression approach: A case study of Sub Saharan African region. International Journal of A frican Studies. 1(2), 10-20. doi: 10.51483/ IJAFRS.1.2.2021.10-20. 